\title{
Regional and national differences in stressful life events: The role of cultural factors, economic development and gender.
}

\author{
José Juan Vázquez \\ Dept. Social Psychology \\ Instituto Universitaro de Investigación en Estudios Latinoamericanos (IELAT) \\ Universidad de Alcalá
}

\section{Sonia Panadero}

Dept. Clincal Psychology

Universidad Complutense de Madrid

\section{Rosa María Martín \\ Dept. Social Psychology \\ Universidad de Alcalá}

\begin{abstract}
The study analyzed differences in the risk of experiencing stressful life events (SLE) according to cultural factors, the level of economic development of the region inhabited and gender. Information was gathered on the number and nature of SLE experienced by a sample of 604 undergraduates from three regions with very different levels of economic development: Madrid (Spain), León (Nicaragua) and Bilwi (Nicaragua). The results indicated a greater risk of experiencing SLE among undergraduates from Nicaragua, but few differences due to the undergraduates' gender or the level of economic development in the region they inhabit within the same country.
\end{abstract}




\section{Regional and national differences in stressful life events: The role of cultural factors, economic development and gender.}

\section{Introduction}

Stressful life events (SLEs) are experiences that play a key role in one's life and that frequently cause significant changes for the person involved. There are significant differences in the number of SLEs experienced by populations with similar demographic characteristics depending on the level of economic development in their countries: the inhabitants of less developed countries appear to be more prone to experiencing SLEs (Vazquez, Panadero, \& Rincón, 2007). According to Hatch and Dohrenwend (2007), there have been few studies of the distribution of SLEs by gender, especially in contexts of low levels of economic and social development. There is some consensus that men and women experience different types of SLEs. While women tend to experience SLEs of a more interpersonal nature, rape and sexual assault, men experience SLEs that are more related to legal and employment issues, as well as injury traumas, serious accidents, illness and hospitalization (Hatch \& Dohrenwend, 2007).

Few studies in the literature analyze whether the differences in experiencing SLEs not only occur across countries with different levels of economic and social development, but also across regions with similar cultural references but different levels of development in the same country. Such studies would permit analysis of the role of the level of economic development and cultural factors in the occurrence of these stressful life events. Nor have there been any studies of the differences in experiencing SLEs according to the gender of the individual in combination with the level of his or her country's economic and social development.

In order to provide some such analysis, this study was conducted with undergraduates in two countries with different levels of economic and social development: Spain (ranked 23 in the Human Development Index - HDI) and Nicaragua (ranked 129 in the HDI) (UNDP, 2011). All the Spanish participants were students in Madrid, while the Nicaraguan participants studied in León (Departamento de León) and Bilwi (Región Autónoma del Atlántico Norte-RAAN), cities in regions with different economic and social levels of development. The RAAN has the lowest levels of economic development in Nicaragua and, according to the United Nations Development Program (UNDP), a low HDI as opposed to the Departamento de León's medium level HDI.

\section{Method}

Six hundred four undergraduates took part in the study, 156 men $(25.8 \%)$ and 448 women $(74.2 \%)$, with a mean age of 21.94 years old $(S D=4.46)$. Of these, 336 were studying in Madrid (Spain) (65.6\% women and 34.4\% men; $M$ age=21.63; SD=4.08), 167 were studying in León (Nicaragua) (86.7\% women and $13.3 \%$ men; $M$ age=20.92; $S D=2.46$ ) and 101 were studying in Bilwi (Nicaragua) (61.3\% women and 38.7\% men; $M$ age $=21.96 ; S D=3.48$ ). 
All the participants were undergraduates from one of the following universities: Complutense University of Madrid (Spain), University of Alcalá (Spain), National Autonomous University of Nicaragua in León (Nicaragua) or University of the Autonomous Regions of the Caribbean Coast Nicaragua (URACCAN) in Bilwi (Nicaragua).

Access to the students in their randomly chosen classrooms was achieved with the collaboration of the centres' faculty and managerial staff. After indicating that participation was completely voluntary, students were informed that the questionnaires would be completed anonymously and that the data collected would be used exclusively for research purposes. The participants were asked to give their informed consent. The questionnaires were completed by groups of students simultaneously.

In order to collect information on the SLEs suffered by the interviewees, a list of twenty selected vital events was used (see tables 1, 2, and 3). This list was created after reviewing the SLEs considered in other studies conducted on different Spanish-speaking populations (Vázquez et al., 2007). Participants had to respond if they had experienced each of the SLEs or not (dichotomizing answer).

Differences in SLEs experienced across different regions and according to gender were identified. For nominal-level data, the statistical significance of the differences was tested using chi-square analyses. For interval-level data, the differences were tested using $t$ tests. Levene tests for variance equality were computed prior to calculating the $t$ tests. If the variances in the two groups were not the same, the separate variance formula was used to calculate the $t$ test. If the variances were the same, the basic pooled variance formula was used. The risk of each SLE for individuals from the different places was compared. In univariate analyses, the odds ratios were computed with $95 \%$ confidence intervals using standard methods.

\section{Results}

The results showed differences in terms of the number of SLEs experienced by undergraduates in Madrid, León and Bilwi $\left(F_{2}=116.68, \mathrm{p}<.001\right)$. The mean number of SLEs experienced by students from Madrid ( $M$ SLEs $=0.92 ; S D=1.42)$ was significantly lower $(t=7.68$, $\mathrm{p}<.001)$ than the amount experienced by students in Bilwi ( $M$ SLEs=3.18; $S D=2.26)$ and in León

(M SLEs=3.44; $S D=2.27)(t=7.69, \mathrm{p}<.001)$. However, there were no statistically significant differences in the mean number of SLEs experienced by the participants in Bilwi and León.

There were significant differences between undergraduates from Spain and Nicaragua with respect to their experience of several specific SLEs (Table 1 and Table 2). 
Table 1. Frequency (\%) of Stressful Life Events among Spanish (Madrid) and Nicaraguan (Bilwi) Participants

\begin{tabular}{|c|c|c|c|c|c|}
\hline \multirow[b]{2}{*}{ Stressful Life Events } & \multicolumn{2}{|c|}{ Frequency } & \multirow[b]{2}{*}{$x^{2}$} & \multirow[b]{2}{*}{$\begin{array}{l}\text { Odds } \\
\text { ratio }\end{array}$} & \multirow[b]{2}{*}{$95 \% \mathrm{CI}$} \\
\hline & $\begin{array}{c}\text { Madri } \\
\text { d } \\
\text { (Spain) }\end{array}$ & $\begin{array}{l}\text { Bilwi } \\
\text { (Nica- } \\
\text { ragua } \\
\text { ) }\end{array}$ & & & \\
\hline Parental drug/alcohol abuse (before 18 yr.) & 3.9 & 23.6 & $37.05 * * *$ & 7.65 & $3.65-16.02$ \\
\hline $\begin{array}{l}\text { Parental mental and physical health } \\
\text { problems (before } 18 \mathrm{yr} \text {.) }\end{array}$ & 13.4 & 15.6 & .30 & & \\
\hline Physical/sexual abuse (before 18 yr.) & 3.0 & 10.8 & $9.91 * *$ & 3.93 & $1.58-9.75$ \\
\hline Ran away from home (before 18 yr.) & 3.0 & 8.5 & $5.61 *$ & 3.03 & $1.16-7.92$ \\
\hline Parental divorce/separation (before $18 \mathrm{yr}$.) & 10.2 & 45.3 & $61.82 * * *$ & 7.30 & $4.26-12.49$ \\
\hline $\begin{array}{l}\text { Raised by people other than parents (before } \\
\qquad 18 \mathrm{yr} \text {.) }\end{array}$ & 3.9 & 13.5 & $12.22 * * *$ & 3.87 & $1.73-8.66$ \\
\hline Father's death & 3.3 & 16.1 & $21.05 * * *$ & 5.66 & $2.50-12.81$ \\
\hline Mother's death & 1.8 & 11.7 & $19.02 * * *$ & 7.30 & $2.62-20.28$ \\
\hline Death of spouse or partner & .0 & 5.4 & $18.28 * * *$ & & \\
\hline Illness or injury & 7.4 & 29.8 & $33.94 * * *$ & 5.28 & $2.89-9.63$ \\
\hline Divorce/separation & .0 & 14.9 & $51.73 * * *$ & & \\
\hline Significant economic problems & 4.8 & 48.9 & $116.1 * * *$ & 19.17 & $10.06-36.52$ \\
\hline Significant unemployment problems & 3.3 & 37.0 & $86.80 * * *$ & 17.27 & $8.28-36.01$ \\
\hline Excessive consumption of drugs or alcohol & 10.7 & 7.4 & .87 & & \\
\hline Mental health problems & 1.2 & 8.6 & $14.72 * * *$ & 7.81 & $2.30-26.56$ \\
\hline $\begin{array}{l}\text { Loss of home due to eviction, demolition or } \\
\text { other causes }\end{array}$ & .9 & 20.8 & $58.90 * * *$ & 29.21 & $8.46-100.82$ \\
\hline Change of residence because of work & 16.7 & 27.4 & $5.51 *$ & 1.88 & $1.10-3.21$ \\
\hline Physical/sexual abuse (after 18 yr.) & 1.5 & 9.7 & $15.35 * * *$ & 7.05 & $2.30-21.59$ \\
\hline Spousal/partner abuse & 1.2 & 5.4 & $6.21 *$ & 4.72 & $1.24-17.93$ \\
\hline Suicide attempt & .9 & 11.7 & $27.25 * * *$ & 14.71 & $4.01-53.93$ \\
\hline
\end{tabular}

$* \mathrm{p} \leq .05 ; * * \mathrm{p} \leq .01 ; * * * \mathrm{p} \leq .001$ 
Table 2. Frequency (\%) of Stressful Life Events among Spanish (Madrid) and Nicaraguan (León) Participants

\begin{tabular}{|c|c|c|c|c|c|}
\hline \multirow[b]{2}{*}{ Stressful Life Events } & \multicolumn{2}{|c|}{ Frequency } & \multirow[b]{2}{*}{$x^{2}$} & \multirow[b]{2}{*}{$\begin{array}{l}\text { Odds } \\
\text { ratio }\end{array}$} & \multirow[b]{2}{*}{$95 \% \mathrm{CI}$} \\
\hline & $\begin{array}{c}\text { Madri } \\
\text { d } \\
\text { (Spain) }\end{array}$ & $\begin{array}{l}\text { León } \\
\text { (Nica- } \\
\text { ragua } \\
\quad \text { ) }\end{array}$ & & & \\
\hline Parental drug/alcohol abuse (before 18 yr.) & 3.9 & 33.9 & $83.97 * * *$ & 12.72 & $6.70-24.16$ \\
\hline $\begin{array}{l}\text { Parental mental and physical health } \\
\text { problems (before } 18 \mathrm{yr} \text {.) }\end{array}$ & 13.4 & 25.9 & $11.80 * * *$ & 2.26 & $1.41-3.61$ \\
\hline Physical/sexual abuse (before 18 yr.) & 3.0 & 17.0 & $30.91 * * *$ & 6.66 & $3.15-14.09$ \\
\hline Ran away from home (before 18 yr.) & 3.0 & 5.5 & 1.86 & 1.88 & $.75-4.72$ \\
\hline Parental divorce/separation (before $18 \mathrm{yr}$.) & 10.2 & 50.0 & $97.12 * * *$ & 8.82 & $5.52-14.11$ \\
\hline $\begin{array}{l}\text { Raised by people other than parents } \\
\quad \text { (before } 18 \mathrm{yr} \text {.) }\end{array}$ & 3.9 & 14.0 & $16.84 * * *$ & 4.03 & $1.9-8.180$ \\
\hline Father's death & 3.3 & 11.0 & $11.90 * * *$ & 3.63 & $1.67-7.88$ \\
\hline Mother's death & 1.8 & 1.8 & .00 & & \\
\hline Death of spouse or partner & .0 & 1.9 & $6.50 *$ & & \\
\hline Illness or injury & 7.4 & 29.7 & $43.54 * * *$ & 5.25 & $3.10-8.90$ \\
\hline Divorce/separation & .0 & 2.0 & $6.85 * *$ & & \\
\hline Significant economic problems & 4.8 & 69.7 & $241.63 * * *$ & 46.00 & $25.20-83.98$ \\
\hline Significant unemployment problems & 3.3 & 19.6 & $36.77 * * *$ & 7.19 & $3.51-14.74$ \\
\hline Excessive consumption of drugs or alcohol & 10.7 & 6.7 & 2.08 & & \\
\hline Mental health problems & 1.2 & 2.4 & 1.09 & & \\
\hline $\begin{array}{l}\text { Loss of home due to eviction, demolition } \\
\text { or other causes }\end{array}$ & .9 & 5.5 & $10.02 * *$ & 6.49 & $1.73-24.30$ \\
\hline Change of residence because of work & 16.7 & 28.4 & $9.23 * *$ & 1.98 & $1.27-3.10$ \\
\hline Physical/sexual abuse (after 18 yr.) & 1.5 & 6.7 & $9.70 * *$ & 4.76 & $1.63-13.94$ \\
\hline Spousal/partner abuse & 1.2 & 6.4 & $10.50 * * *$ & 5.68 & $1.75-18.42$ \\
\hline Suicide attempt & .9 & 10.9 & $27.64 * * *$ & 13.59 & $3.94-46.85$ \\
\hline
\end{tabular}

$* \mathrm{p} \leq .05 ; * * \mathrm{p} \leq .01 ; * * \mathrm{p} \leq .001$

There were relatively few statistically significant differences between Nicaraguan undergraduates from León and Bilwi with respect to their experience of certain SLEs (Table 3). 
Table 3. Frequency (\%) of Stressful Life Events among Nicaraguan (Bilwi and León) Participants

\begin{tabular}{|c|c|c|c|c|c|}
\hline \multirow[b]{2}{*}{ Stressful Life Events } & \multicolumn{2}{|c|}{ Frequency } & \multirow[b]{2}{*}{$x^{2}$} & \multirow[b]{2}{*}{$\begin{array}{l}\text { Odds } \\
\text { ratio }\end{array}$} & \multirow[b]{2}{*}{$95 \% \mathrm{CI}$} \\
\hline & $\begin{array}{c}\text { Bilwi } \\
\text { (Nicara- } \\
\text { gua) }\end{array}$ & $\begin{array}{c}\text { León } \\
\text { (Nicara- } \\
\text { gua) }\end{array}$ & & & \\
\hline $\begin{array}{l}\text { Parental drug/alcohol abuse (before } 18 \\
\text { yr.) }\end{array}$ & 23.6 & 33.9 & 2.93 & 1.66 & \\
\hline $\begin{array}{l}\text { Parental mental and physical health } \\
\text { problems (before } 18 \mathrm{yr} \text {.) }\end{array}$ & 15.6 & 25.9 & 3.72 & 1.89 & \\
\hline Physical/sexual abuse (before 18 yr.) & 10.8 & 17.0 & 1.83 & 1.70 & \\
\hline Ran away from home (before $18 \mathrm{yr}$.) & 8.5 & 5.5 & .91 & .62 & \\
\hline $\begin{array}{l}\text { Parental divorce/separation (before } 18 \\
\text { yr.) }\end{array}$ & 45.3 & 50.0 & .54 & 1.21 & \\
\hline $\begin{array}{l}\text { Raised by people other than parents } \\
\text { (before } 18 \mathrm{yr} \text {.) }\end{array}$ & 13.5 & 14.0 & .12 & 1.04 & \\
\hline Father's death & 16.1 & 11.0 & 1.41 & .64 & \\
\hline Mother's death & 11.7 & 1.8 & $11.26^{* * *}$ & .14 & $.38-.52$ \\
\hline Death of spouse or partner & 5.4 & 1.9 & 2.23 & .34 & \\
\hline Illness or injury & 29.8 & 29.7 & .00 & 1.00 & \\
\hline Divorce/separation & 14.9 & 2.0 & $14.57 * * *$ & .12 & $.03-.42$ \\
\hline Significant economic problems & 48.9 & 69.7 & $10.97 * * *$ & 2.40 & $1.42-4.05$ \\
\hline Significant unemployment problems & 37.0 & 19.6 & $9.08 * *$ & .42 & $.23-.74$ \\
\hline $\begin{array}{l}\text { Excessive consumption of drugs or } \\
\text { alcohol }\end{array}$ & 7.4 & 6.7 & .50 & .89 & \\
\hline Mental health problems & 8.6 & 2.4 & 5.06 & .27 & \\
\hline $\begin{array}{l}\text { Loss of home due to eviction, } \\
\text { demolition or other causes }\end{array}$ & 20.8 & 5.5 & $14.25 * * *$ & .22 & $.97-.51$ \\
\hline Change of residence because of work & 27.4 & 28.4 & .31 & 1.05 & \\
\hline Physical/sexual abuse (after 18 yr.) & 9.7 & 6.7 & .70 & .67 & \\
\hline Spousal/partner abuse & 5.4 & 6.4 & .11 & 1.20 & \\
\hline Suicide attempt & 11.7 & 10.9 & .38 & .92 & \\
\hline
\end{tabular}

$* \mathrm{p} \leq .05 ; * * \mathrm{p} \leq .01 ; * * * \mathrm{p} \leq .001$

No statistically significant differences were found regarding the mean number of SLEs experienced by Spanish men and women ( $M$ SLEs=1.04; $S D=1.63$, and $M$ SLEs=0.91; $S D=1.36$ respectively) $(t=0.75, \mathrm{p}<.450)$, or by Nicaraguan men and women ( $M$ SLEs $=3.19 ; S D=2.10$, and $M$ SLEs=3.65; $S D=2.41$ respectively) $(t=1.40, p<.164)$. Statistically significant differences by gender were only observed among undergraduates in Spain for the risk of "Excessive consumption of drugs or alcohol" (17.2\% men and 7.9\% women; $\left.X^{2}=6.28, \mathrm{p}<.05\right)$. The odds ratios indicate that the risk of "Excessive composition of drugs or alcohol" is higher among men than among women in Spain $(O R=0.41 ; 95 \% C I=0.20-0.84)$. Meanwhile, among undergraduates 
in Nicaragua, women appear to have experienced "Physical/sexual abuse (before $18 \mathrm{yr}$.)" to a greater extent than men $\left(6.3 \%\right.$ men and $18.6 \%$ women, $\left.X^{2}=.70, p<.05\right)$ as well as "Spousal/partner abuse" ( $1.6 \%$ men and $10.1 \%$ women, $X^{2}=4.85, p<.05$.) The odds ratios indicate that the risk of experiencing "Physical / sexual abuse (before 18 yr.)" and "Spousal/partner abuse" is significantly higher among women than among men in Nicaragua $(O R=3.42$; 95\% CI=1.189.91 and $O R=7.10 ; 95 \% C I=0.94-53.51$, respectively).

\section{Discussion}

The results showed a relationship between the experience of SLEs and the level of economic development of the country where the students lived. The number of SLEs experienced by undergraduates from Nicaragua was almost four times higher than that experienced by students from Spain, which increased the risk among the former of suffering from physical and mental health problems (Hackett et al., 2000; Croply \& Steptoe, 2005; Hatch \& Dohrenwend, 2007). Likewise, the risk of suicidal behaviour among Nicaraguan undergraduates was 14 times higher than among their Spanish counterparts.

The major economic differences between Nicaragua and Spain may help to explain this variation in the risk of experiencing certain SLEs, especially those related to financial issues (the risk of financial problems for Madrid undergraduates was 46 times lower than for students from León, while the risk of unemployment problems for the same students was 17 times lower than for students from Bilwi) and health (the risk of illness or injury for undergraduates in Nicaragua was five times greater than for those in Madrid). These differences in the risk of experiencing health problems could be related to issues such as differences in lifestyle, diet, health education, housing quality and amenities, and access to quality health care (Vázquez et al., 2007), all of which are largely related to financial issues.

The results also showed significant differences with respect to experiencing SLEs in the early years of life. The risks of Nicaraguan undergraduates experiencing "Parental drug/alcohol abuse", "Parental divorce/separation" or being "Raised by people other than parents" were approximately ten, eight and four times higher respectively than fore Spanish undergraduates. These indicators of family breakdown could be associated with the increased risk among Nicaraguan undergraduates of experiencing "Physical / sexual abuse" (approximately five times higher than among Spanish students). This issue has been linked with a broad range of psychiatric disorders (Shapiro et al., 2012; Sugaya et al., 2012). While the different levels of risk of experiencing early SLEs may be indirectly related to the economic environment, they appear to be much more related to cultural variables. In fact, no statistically significant differences were observed between the inhabitants of the two regions in Nicaragua, which have similar cultural characteristics but different levels of economic development.

With respect to the issue of gender violence, the available data suggest the existence of differences between Nicaragua and Spain. Thus, while in Nicaragua $23 \%$ of women between 20 and 24 years old have been affected by this kind of violence (Bott, Guedes, Goodwin, \& 
Mendoza, 2012), in Spain, official data speak of $12.3 \%$ women (under thirty years old) affected by the same phenomenon (Observatorio de la Violencia de Género, 2011).

This study's results are consistent with these data. Although the figures are lower, probably due to the younger age of the participants and other factors related to the composition of the sample (i.e. the educational level of the participants), significant differences were observed between undergraduates from Spain and Nicaragua in terms of risk of "Spousal/partner abuse". These experiences of abuse may be related to the differences in the risk of "Divorce / separation". Differences in both issues may be mainly due to cultural factors: marriage and cohabitation tended to occur at much younger ages in Nicaragua than in Spain, thus facilitating the divorce and separation at an earlier age, and pregnancies, often unwanted or unplanned, were more common among young Nicaraguan adolescents. Also, differences between Spanish and Nicaraguan the cultural conceptions of the roles of men and women in relationships (Vázquez, 2013) may help explain the high risk of experiencing domestic violence among female Nicaraguan undergraduates.

Only minor differences were observed in the risk of experiencing SLEs according to the level of economic development of the region inhabited within the same country, with similar cultural references across regions. This should problematize the relationship between economic development and risk of experiencing SLEs observed when comparing countries with significant cultural differences. In fact, with respect to the risk of experiencing SLEs related to financial issues, the data were not consistent among the participants from León and Bilwi. However, those same participants did show differences regarding their experience of several specific SLEs, with a higher risk among the university students from the region with lowest level of development.

The results showed no differences according to gender in the mean number of SLEs experienced, whether among university students in Spain or among their Nicaraguan counterparts. However, some isolated differences were observed in relation to certain specific SLEs. Male undergraduates from Spain were at greater risk of excessive consumption of alcohol or drugs than Spanish women, a difference that was not observed among students in Nicaragua. Female undergraduates in Nicaragua were at a higher risk than male students in the country of experiencing physical or sexual abuse before the age of 18 years old and of experiencing abuse from their spouse or partner. Spanish undergraduates presented no difference in this respect since this type of stressful event was experienced by only a small percentage of the students interviewed.

It should be noted that this study was subject to some limitations which mainly derived from the use of samples from a very specific sector of the population, namely undergraduates. As a result, the findings can scarcely be generalized. This sector differs in significant ways (culturally, economically and politically) from the group of young people and, of course, from the overall population. Further limitations stem from the use of self-reported measures, which are subject to different biases. Finally, the study's observational design means that causal relations cannot be determined. 


\section{References}

Bott, S., Guedes, A., Goodwin, M., \& Mendoza, J.A. (2012). Violence Against Women in Latin America and the Caribbean: A comparative analysis of population-based data from 12 countries. Washington, DC: PAHO.

Croply, M. \& Steptoe, A. (2005). Social support, life events and physical symptoms: A prospective study of chronic and recent life stress in men and women. Psychology, Health, \& Medicine, 10, 317-325.

Hackett, R., Hackett, L., Bhakta, P., \& Gowers, S. (2000). Life events in a south Indian population and their association with psychiatric disorder in children. International Journal of Social Psychiatry, 46, 201-207.

Hatch, S.L. \& Dohrenwend, B.P. (2007). Distribution of traumatic and other stressful life events by race/ethnicity, gender, SES, and age: A review of the research. American Journal or Community Psychology, 40, 313-332.

Shapiro, D.N., Kaplow, J.B., Amaya-Jackson, L., \& Dodge, K.A. (2012). Behavioral markers of coping and psychiatric symptoms among sexually abused children. Journal of Traumatic Stress, 25(2), 157-163.

Sugaya, L., Hasin, D.S., Olfson, M., Lin, K.H., Grant, B.F., \& Blanco, C. (2012) Child physical abuse and adult mental health: A national study. Journal of Traumatic Stress, 25(4), 384392.

Observatorio de la Violencia de Género (2011). Macroencuesta sobre la violencia de género 2011. Madrid: Ministerio de Sanidad, Servicios Sociales e Igualdad.

UNDP (United Nations Development Program) (2011). Human Development Report 2011. Sustainability and Equity: A Better Future for All. New York: Author.

Vázquez, J.J. (2013). Happiness among the garbage. Differences in overall happiness among trash pickers in León (Nicaragua). The Journal of Positive Psychology, 8(1), 1-11.

Vázquez, J.J., Panadero, S. \& Rincón, P.P. (2007). Stressful life events in countries of differing economic development: Nicaragua, Chile, and Spain. Psychological Reports, 101, 193-201. 